кандидат психологічних наук, доцент, доцент кафедри загальної психології та психодіагностики Рівненського державного гуманітарного університету https://orcid.org/0000-0003-0200-1982.

DOI https://doi.org/10.35619/praprv.v1i16.221

\title{
СТИЛЬОВІ ОСОБЛИВОСТІ САМОРЕГУЛЯЦЇ̈ ПОВЕДІНКИ МАЙБУТНІХ ФАХІВЦІВ-ПСИХОЛОГІВ
}

\begin{abstract}
Анотація. $У$ статті представлено результати дослідження стильових особливостей саморегуляиії поведінки майбутніх фахівців-психологів на різних етапах їх фахової підготовки. За результатами проведеного дослідження виявлено, що характер розвитку основних регуляторних процесів (планування иілей діяльності, моделювання значущчих умов, програмування дій, оцінка і корекиія результатів) та регуляторноособистісних властивостей (гнучкість і самостійність) майбутніх фахівців-психологів має свої специфічні особливості на різних етапах їх учбово-професійної підготовки.

Виявлено, щчо у порівнянні зі студентами першого курсу, у студентів четвертого курсу спостерігається достовірно вищий ступінь розвитку основних регуляторних процесів та регуляторно-особистісних властивостей: загального рівня саморегуляиії як здатності до усвідомленої саморегулячії довільної активності; гнучкості як здатності до перебудови та корекиії системи саморегуляиії при зміні зовнішніх $і$ внутрішніх умов; оцінки $і$ корекції результатів як здатності до адекватної та автономної оцінки себе і результатів своєї діяльності та поведінки; моделювання значущих умов як ступеня розвитку уявлень про систему зовнішніх і внутрішньо значущих для досягнення цілей умов, їх усвідомленості та деталізованості; самостійності як ступеня розвитку регуляторної автономності; програмування дій як ступеня усвідомленої побудови способів і послідовності власних дій для досягнення поставлених иілей; планування иілей діяльності як ступеня розвитку механізмів цілепокладання з точки зору усвідомленості й автономності процесу висунення цілей активності, їх дієвості, реалістичності, деталізованості та стійкості.
\end{abstract}

Ключові слова: саморегулячія, регуляторні процеси, регуляторно-особистісні властивості, компоненти саморегуляиї̈ поведінки, студенти-психологи, фахова підготовка.

Постановка проблеми. Сучасний етап розвитку вітчизняної сфери вищої освіти пред'являє високі вимоги до особистості майбутнього фахівця, перш за все, його здатності долати труднощі об'єктивного і суб'єктивного характеру у процесі учбово-професійної підготовки. У цьому процесі здобувач вищої освіти розглядається як суб'єкт ініціації власної довільної і усвідомленої активності в напрямку забезпечення оптимальної регуляції взаємовідносин $з$ освітнім середовищем. Одним із найбільш загальних і суттєвих проявів такої суб'єктної позиції майбутнього фахівця є здатність до саморегуляції власної поведінки в умовах навчальної діяльності. Успішна саморегуляція суб'єктів освітнього процесу у вищій школі забезпечує необхідний рівень оптимальної мобілізації власних потенційних можливостей у напрямку розвитку професійних здібностей, актуалізації і реалізації їх особистісного та інтелектуального потенціалу.

Особливого значення здатність до саморегуляції власної поведінки в умовах навчальної діяльності набуває у системі фахової підготовки майбутніх фахівців соціономічного профілю, зокрема, майбутніх психологів. Здатність до саморегуляції поведінки стає не лише визначальним чинником ефективного вирішення актуальних проблем і задач їх навчальної діяльності, але і професійно важливою якістю у структурі їх професійної компетентності. Незважаючи на репрезентативний теоретичний та емпіричний досвід розробки проблеми саморегуляції поведінки майбутніх фахівців в умовах їх 
навчальної діяльності, фактично відсутні розвідки, присвячені вивченню особливостей саморегуляції поведінки майбутніх фахівців-психологів на різних етапах їх фахової підготовки.

Аналіз останніх досліджень 3 проблеми. У вітчизняній психологічній науці питання саморегуляції поведінки майбутніх фахівців вивчаються у напрямку аналізу особливостей саморегуляції у процесі професійного становлення (Гринціва, 2016); вивчення стильових особливостей саморегуляції у аспірантів технічного і гуманітарного профілів (Джагарян, Сінченко, 2010); простеження стилів саморегуляції учбової діяльності здобувачів вищої освіти (Киселевська, 2005); формування механізмів саморегуляції студентів в іншомовному просторі (Тетерук, 2006); підготовки майбутнього вчителя до саморегуляції педагогічної діяльності (Чайка, 2006); аналізу психологічні чинники саморегуляції поведінки студентської молоді в процесі соціалізації (Шавиро, 2014); розвитку просоціальних тенденцій як особистісної складової майбутньої професійної діяльності психолога (Корчакова, 2014.) простеження розвитку емоційно-вольової саморегуляції студентів в умовах вищого навчального закладу (Шевченко, 2010)

У зарубіжній науково-психологічній традиції також виконано ряд досліджень за означеним напрямком. Зокрема вивчаються питання поведінкових, емоційних та когнітивних аспектів саморегуляції студентів (Сан, Руеда, 2012); особливості саморегуляції і мотивації навчальної діяльності студентів (Ціммерман, 2008); метакогнітивні аспекти дослідження саморегуляції навчальної діяльності (Забруцькі, 2008), Шроу, Гріппен, Реса, 2006); саморегуляція і самоефективність студентів (Шунка, Ертмера, Бокартса, Пінтріха, Зайднера, 2000).

Система саморегуляції має певну структурну організацію. В якості основних структурних елементів саморегуляції виокремлюють: зміст, процес, самооцінку (Моросанова, 2010). Зокрема, змістовими структурними елементами саморегуляції виступають джерела активності особистості, іï внутрішня мотивація; процесуальні структурні елементи саморегуляції пов'язані з тими чи іншими варіантами регуляції діяльності на певному рівні досягнень; основу самооцінювання складають мотиви, спрямованість, засоби та оцінка результатів діяльності.

Для вивчення індивідуально-типологічних особливостей системи регуляції довільної активності особистості запропоновано поняття «індивідуального стилю саморегуляиї». До стильових особливостей саморегуляції входять індивідуальні особливості регуляторних процесів - цілі, моделювання умов, програмування дій, оцінювання результатів, а також стильові особливості (регуляторно-особистісні властивості) - самостійність, ініціативність, гнучкість (Моросанова, 2010). Індивідуальний стиль саморегуляції, який характеризується рівнем розвитку регуляторних процесів та регуляторних властивостей особистості, забезпечує необхідну основу для формування системи особистісних компетентностей майбутніх фахівців, які визначатимуть якість їх фахової підготовки: вміння ставити цілі i визначати найбільш пріоритетні з них, аналізувати умови і виділяти найбільш важливі $з$ них для досягнення поставленої мети, вибирати оптимальні способи дій і організовувати їхню послідовну реалізацію, оцінювати проміжні та кінцеві результати діяльності, корегувати власну діяльність. Система саморегуляції поведінки майбутніх фахівців у процесі їх учбової (навчальної) діяльності має ту ж структуру, що і саморегуляція будь-якої іншої діяльності. Структурними компонентами саморегуляції поведінки майбутніх фахівців виступають: планування, визначення мети навчальної діяльності та послідовності здійснення цілей навчання; моделювання, урахування значущих умов навчальної діяльності, необхідних для іiі виконання; програмування та визначення послідовності виконання дій навчальної діяльності; оцінка результатів та їх співвідношення 3 критеріями, визначеними викладачем чи самим студентом; контроль за результатами та корекція навчальних дій на основі індивідуально прийнятих еталонів успішності (Моросанова, 1994).

У контексті обгрунтування структури саморегуляції майбутніх фахівців використовують поняття «професійної саморегулящї»» (Чайка, 2006). В якості компонентів професійної саморегуляції майбутніх фахівців виокремлюють: мотиваційний, який 
відображає усвідомлені студентами моральні поняття, загальнокультурні та професійнопедагогічні цінності, спрямовані на оволодіння професією; рефлексивний, який передбачає порівняння студентом свого досвіду з досвідом інших людей; емочійно-вольовий, який полягає в умінні виявляти витримку, усвідомлювати власні почуття, регулювати свої стосунки та спілкуватися; діяльнісний, який передбачає вміння студента здійснювати самоконтроль, самокорекцію поведінки, усвідомлювати мету власних дій. Високий рівень розвитку процесів саморегуляції у студентів пов'язаний з докорінною трансформацією їх ставлення до власної навчальної діяльності. Майбутній фахівець не просто передбачає результати своїх дій, але i починає довільно організовувати їх: формулювати i обгрунтовувати цілі, аналізувати їх з точки зору значущості та можливості досягнення, створювати нові способи їх здійснення. Він не просто контролює свої дії шляхом порівняння їх результатів з еталоном, але й визначає різноманітні критерії, показники контролю і оцінки. Тобто, майбутній фахівець починає опановувати процес управління власною навчальною діяльністю.

Саморегуляція поведінки студентів у процесі їх учбово-професійної підготовки відбувається у площині двох взаємопов'язаних процесів. 3 одного боку, процеси саморегуляції спрямовані на регуляцію актуальної навчальної діяльності майбутнього фахівця, тобто вирішення поточних задач і проблем, що виникають в процесі його учбовопрофесійної підготовки, а 3 іншого, - на розвиток системи фахових знань, вмінь та здібностей як основи для повного i максимального розкриття його особистісного i професійного потенціалу. Відтак вивчення стильових особливостей саморегуляції поведінки майбутніх фахівців у процесі учбово-професійної діяльності стає важливим фактором розуміння не лише умов забезпечення якості їх фахової підготовки, але і умов формування системи їх особистісних компетентностей.

Мета статті полягає у дослідженні стильових особливостей саморегуляції поведінки майбутніх фахівців-психологів на різних етапах фахової підготовки.

Методика та організація дослідження. У ході емпіричного дослідження перевірялась гіпотеза про те, що характер саморегуляції поведінки майбутніх фахівцівпсихологів має свої специфічні особливості прояву на різних етапах їх фахової підготовки. Перевірку припущення було здійснено за участю студентів-психологів старшого (IV-го) i молодшого (I-го) курсів навчання. Репрезентативна вибірка випробуваних у кількості 72 осіб була сформована методом рандомізованого відбору з числа здобувачів вищої освіти Рівненського державного гуманітарного університету.

3 метою вивчення особливостей саморегуляції поведінки майбутніх фахівцівпсихологів на різних етапах їх фахової підготовки було використано опитувальник «Стиль саморегуляції поведінки» (авт. Моросанова, 2004). Опитувальник в цілому працює як єдина шкала «загальний рівень саморегуляції» і складається з 46 тверджень, що входять до складу шести шкал, які виділяються відповідно до основних регуляторних процесів і регуляторноособистісних властивостей. Психологічними шкалами, які вимірювались у випробуваних в ході дослідження, визначено:

- планування циілей діяльності (ступінь розвитку цілепокладання 3 точки зору усвідомленості й автономності процесу висунення цілей активності, їх дієвості, реалістичності, стійкості, деталізованості);

- моделювання значущих умов (ступінь розвитку уявлень про систему зовнішніх і внутрішньо значущих для досягнення цілей умов, їх усвідомлення, деталізованості й адекватності);

- програмування дій (ступінь усвідомленої побудови способів і послідовності власних дій для досягнення поставлених цілей);

- оцінка і корекція результатів (ступінь адекватності, автономності оцінки себе і результатів своєї діяльності та поведінки, стійкість суб'єктивних критеріїв оцінки успішності досягнення результатів); 
- гнучкість (ступінь сформованості регулятивної гнучкості або здатність перебудовувати, вносити корективи в систему саморегуляції при зміні зовнішніх i внутрішніх умов);

- самостійність (ступінь регуляторної автономності);

- загальний рівень саморегуляиії (загальний ступінь сформованості індивідуальної системи усвідомленої саморегуляції довільної активності).

Аналіз даних було здійснено за допомогою методу порівняння середніх значень (Бююль, \& Цёфель, 2002) і непараметричного методу відмінностей для незалежних вибірок Манна-Вітні (Наследов, 2004).

Виклад основного матеріалу дослідження. За результатами проведення емпіричного дослідження було виявлено ряд важливих закономірностей (див. табл. 1). Враховуючи характер отриманих результатів, їх аналіз та інтерпретацію проведемо $з$ урахуванням рівня достовірності виявлених закономірностей - від найбільш до найменш значимих результатів.

Таблиия 1.

Відмінності середніх значень вираженості показників саморегуляцї̈ поведінки майбутніх психологів на різних етапах їх фахової підготовки

\begin{tabular}{|c|c|c|c|}
\hline \multirow{2}{*}{ Показники саморегуляції поведінки } & \multicolumn{2}{|c|}{ Курс підготовки } & \multirow{2}{*}{$\begin{array}{c}\text { Значення } \\
\text { ймовірності } \\
\text { (p) }\end{array}$} \\
\hline & перший & четвертий & \\
\hline планування цілей діяльності & 4,56 & 5,25 & 0,033 \\
\hline моделювання значущих умов & 4,64 & 5,78 & 0,007 \\
\hline програмування дій & 5,47 & 6,56 & 0,019 \\
\hline оцінка і корекція результатів & 4,19 & 5,31 & 0,004 \\
\hline гнучкість & 5,53 & 7,03 & 0,003 \\
\hline самостійність & 6,19 & 7,72 & 0,008 \\
\hline загальний рівень саморегуляції & 30,58 & 37,64 & 0,000 \\
\hline
\end{tabular}

На підставі аналізу табличних даних, можна констатувати, що статистично значимі відмінності у середніх значеннях вираженості показників саморегуляції поведінки майбутніх психологів виявлено у відношенні усіх порівнюваних характеристик: «загального рівня саморегуляціï» $(\mathrm{p} \leq 0,001)$, «гнучкості» $(\mathrm{p} \leq 0,01)$, «оцінки $і$ корекції результатів» $(\mathrm{p} \leq 0,01)$, «моделювання значущих умов» $(\mathrm{p} \leq 0,01)$, «самостійності» $(\mathrm{p} \leq 0,01)$, «програмування дій» $(\mathrm{p} \leq 0,05)$, «планування цілей діяльності» $(\mathrm{p} \leq 0,05)$.

Узагальнення результатів вивчення особливостей саморегуляції поведінки майбутніх психологів на різних етапах їх учбово-професійної підготовки дозволяє констатувати, що у порівнянні зі студентами-психологами першого курсу навчання, у студентів-психологів четвертого курсу спостерігається достовірно вищий ступінь сформованості індивідуальної системи усвідомленої саморегуляції довільної активності («загальний рівень саморегулящії»). Випускники першого (бакалаврського0 ступеня вищої освіти демонструють більшу самостійність, гнучкість і адекватність реагування на зміну умов, у т.ч. пов'язаних 3 навчанням; висунення і досягнення мети у них в значній мірі усвідомлено. При високій мотивації досягнення вони здатні формувати такий стиль саморегуляції, який дозволяє компенсувати вплив особистісних, характерологічних особливостей, що перешкоджають 
досягненню мети; опановувати нові види активності, впевненіше почувати себе в незнайомих ситуаціях; демонструвати більш стабільні успіхи у звичних видах діяльності.

Очевидним $є$ i те, що у порівнянні зі студентами-психологами першого курсу навчання, у студентів випускного курсу спостерігається достовірно вищий ступінь сформованості регулятивної гнучкості, тобто здатності перебудовувати, вносити корективи в систему саморегуляції при зміні зовнішніх і внутрішніх умов («гнучкість»). Студентипсихологи старшого курсу демонструють вищу пластичність усіх регуляторних процесів, що дозволяє їм у випадку виникнення непередбачуваних обставин, у т.ч. пов'язаних 3 їх навчальною діяльністю, легко перебудовувати плани i програми виконавських дій i поведінки, більш швидко оцінювати зміну значущих умов і перебудовувати програму дій; при виникненні неузгодженості отриманих результатів 3 прийнятою метою своєчасно оцінювати сам факт неузгодженості і вносити відповідні зміни; більш адекватно реагувати на швидку зміну подій і успішно вирішувати поставлену задачу в ситуації ризику.

У порівнянні зі студентами-психологами першого курсу навчання, у майбутніх бакалаврів спостерігається достовірно вищий ступінь адекватності, автономності оцінки себе i результатів своєї діяльності та поведінки, стійкості суб'єктивних критеріїв оцінки успішності досягнення результатів («оиінка $і$ корекиія результатів»). Вони більш адекватно оцінюють як сам факт неузгодженості отриманих результатів 3 метою діяльності, так i причини, що призвели до цього, гнучко адаптуючись до зміни умов. Також, у порівнянні зі студентами-психологами першого курсу навчання, у студентів-психологів четвертого курсу спостерігається достовірно вищий ступінь розвиненості уявлень про систему зовнішніх $\mathrm{i}$ внутрішньо значущих для досягнення цілей умов, ступінь їх усвідомленості, деталізованості, адекватності («моделювання значущиих умов»). Вони здатні краще виділяти значущі умови досягнення цілей як в поточній ситуації, так і в перспективному майбутньому, що проявляється у відповідності програм дій планам діяльності, відповідно отриманих результатів прийнятим цілям. У студентів-випускників бакалаврату порівнянні зі студентами-психологами першого курсу спостерігається достовірно вищий ступінь розвиненості регуляторної автономності («самостійність»). Це свідчить про їх кращу автономність в організації власної активності, більш розвинену здатність самостійно планувати діяльність і поведінку, організовувати роботу по досягненню визначеної мети, контролювати хід іiї виконання, аналізувати і оцінювати як проміжні, так і кінцеві результати діяльності (в т.ч., навчальної). Також, у студентів-психологів четвертого курсу навчання у порівнянні зі студентами-психологами першого курсу спостерігається достовірно вищий ступінь усвідомленої побудови способів і послідовності власних дій для досягнення поставлених цілей, а також сформованості потреби продумувати способи своїх дій i поведінки для досягнення намічених цілей. У студентів четвертого курсу у порівнянні зі студентами першого курсу програми розробляються самостійно, вони гнучко змінюються в нових обставинах і стійкі в ситуації перешкод; у разі невідповідності отриманих результатів визначеним цілям проводиться більш ефективна корекція програми дій до отримання прийнятного для них результату.

Насамкінець, у студентів-психологів четвертого курсу навчання у порівнянні зі студентами-психологами першого курсу виявляється достовірно вищий ступінь розвитку індивідуальних механізмів цілепокладання 3 точки зору усвідомленості й автономності процесу висунення цілей активності, їх дієвості, реалістичності, стійкості, деталізованості. Студенти старшого курсу навчання виявляють вищий ступінь сформованості потреби в усвідомленому плануванні діяльності; їх плани в цьому випадку більш реалістичні, деталізовані, ієрархічні і стійкі, цілі діяльності висуваються самостійно.

Висновки і перспективи подальших розвідок. За результатами проведеного емпіричного дослідження стало можливим стверджувати, що характер саморегуляції поведінки майбутніх фахівців-психологів має свої специфічні особливості прояву на різних етапах їх фахової підготовки. Було виявлено, що у порівнянні зі студентами-психологами молодшого курсу, у майбутніх фахівців-психологів старшого курсу навчання спостерігається вищий ступінь сформованості регуляторних процесів $\mathrm{i}$ регуляторно-особистісних 
властивостей. Зокрема, на конкретно-емпіричному рівні за усіма вимірюваними психологічними шкалами студентів-психологів порівнюваних курсів навчання підтверджено статистично значимий характер відмінностей середніх значень їх вираженості.

Перспективу подальших розвідок вбачаємо в напрямку виявлення характеру залежності рівня сформованості регуляторних процесів і регуляторно-особистісних властивостей майбутніх психологів від особливостей та характеру їх учбово-професійної підготовки.

\section{СПИСОК ПОСИЛАНЬ}

Бююль, А. \& Цёфель, П. (2002). SPSS: искусство обработки информации: анализ статистических данных и восстановление скрытых закономерностей. СанктПетербург: ООО “ДиаСофтЮГ”.

Гринців, М. В. (2016) Особливості саморегулячії майбутніх психологів як чинник їхнього професійного становлення. (Дис. ... канд. психол. наук). Київ.

Джагарян, В. Е., Синченко, Т. Ю. (2010) Специфика стилей мышления и стилей саморегуляции у аспирантов гуманитарного и технического профилей. Инновационный потенциал субъектов образовательного пространства в условиях модернизаџии образования, 634-639.

Корчакова, Н. В. Просоціальність як особистісна складова майбутньої професійної діяльності студентів-психологів Наукові записки Наџ. ун-ту «Острозька академія». Серія : Психологія i педагогіка. Остріг. 2014. Вип. 28. С. 84-94. URL: http://nbuv.gov.ua/UJRN/Nznuoapp_2014_28_10

Киселевская, Н. А. (2005) Стили саморегулящии учебной деятельности и их формирование у студентов вуза. (Дис. ... канд. психол. наук). Иркутск.

Моросанова, В. И. (1994). Диагностика индивидуально-стилевых особенностей саморегуляции в учебной деятельности студентов. Вопросы психологии, 4, 134-140.

Моросанова, В. И. (2004). Опросник “Стиль саморегуляции поведения”. Москва.

Моросанова, В. И. (2010). Саморегуляция и индивидуальность человека. Москва: Наука.

Наследов, А. Д. (2004) Математические методы психологического исследования: анализ $и$ интерпретация данных. Санкт-Петербург: Речь.

Тетерук, С. П. (2006) Формування механізмів саморегуляції студентів в іншомовному просторі. (Дис. ... канд. психол. наук). Київ.

Чайка, В. (2006). Підготовка майбутнього вчителя до саморегуляиії педагогічної діяльності. Тернопіль: ТНПУ.

Шавиро, Г. (2014) Психологічні чинники саморегуляції поведінки студентської молоді в процесі соціалізації. Вісник Київського національного університету імені Тараса Шевченка, 1, 86-90.

Шевченко, Н. Ф. (2010) Розвиток емоційно-вольової саморегуляції студентів в умовах вищого навчального закладу. Педагогічні науки: теорія, історія інноваційні технологї, 1 , 270-280.

Schunk, Dale H.; Ertmer, Peggy A., Boekaerts, Monique (Ed); Pintrich, Paul R. (Ed); Zeidner, Moshe (Ed). (2000). Self-regulation and academic learning: Self-efficacy enhancing interventions. Handbook of self-regulation. - San Diego, CA, US: Academic Press. -783 p.

Schraw, G., Crippen, K.J. \& Hartley, K. Res (2006). Promoting Self-Regulation in Science Education: Metacognition as Part of a Broader Perspective on Learning. Research in Science Education. Volume 36 (1-2). - P. 111-139.

Sun, J.C-H. \& Rueda, R. (2012). Situational interest, computer selfefficacy and self-regulation: Their impact on student engagement in distance education. British Journal of Educational Technology. - Volume 43(2). - P. 191-204.

Zabrucky, K.M. (2008). Metacognition and learning. In N. Salkind (Ed.), Encyclopedia of Educational Psychology. - Thousand Oaks, CA: SAGE Publications, Inc. - P. 673-676. 
Zimmermann B. (2008). Investigating Self-Regulation and Motivation: Historical Background, Methodological Developments, and Future Prospects. American Educational Research Journal. Volume 45 (1). - P. 166-183.

\section{REFERENCES}

Byuyul, A. \& Tsyofel, P. (2002) SPSS: iskusstvo obrabotki informatsii: analiz statisticheskih dannyih $i$ vosstanovlenie skryityih zakonomernostey [SPSS: the art of information processing: analyzing statistical data and recovering hidden patterns]. Sankt-Peterburg: OOO "DiaSoftYuG".

Hryntsiv, M. V. (2016) Osoblyvosti samorehuliatsii maibutnikh psykholohiv yak chynnyk yikhnoho profesiinoho stanovlennia. (Dys. ... kand. psykhol. nauk). [Features of self-regulation of future psychologists as a factor in their professional formation. (Dis. ... Cand. Psychol. Sciences)]. Kyiv.

Dzhagaryan, V. E., Sinchenko, T. YU. (2010) Specifika stilej myshleniya i stilej samoregulyacii u aspirantov gumanitaronogo i tekhnicheskogo profilej. [Specificity of the style of thinking and styles of self-regulation in graduate students of humanitarian and technical profiles]. Innovacionnyj potencial sub"ektov obrazovatel'nogo prostranstva $v$ usloviyah modernizacii obrazovaniya. [Innovative potential of subjects of educational space in the context of the modernization of education]. 634-639.

Kiselevskaya, N. A. (2005) Stili samoregulyacii uchebnoj deyatel'nosti $i$ ih formirovanie $u$ studentov vuza. (Dis. ... kand. psihol. nauk). [Styles of self-regulation of educational activities and their formation among students of the university. (Dis. ... Cand. Psychol. Sciences)]. Irkutsk.

Korchakova, N. V. Prosotsialnist yak osobystisna skladova maibutnoi profesiinoi diialnosti studentiv-psykholohiv [Prosociality as a personal component of professional activity of future psychologists] Naukovi zapysky Nats. un-tu «Ostrozka akademiia». Seriia : Psykholohiia i pedahohika. Ostrih. 2014. Vyp. 28. S. 84-94. URL: http://nbuv.gov.ua/UJRN/Nznuoapp_2014_28_10

Morosanova, V. I. (1994). Diagnostika individualno-stilevyih osobennostey samoregulyatsii v uchebnoy deyatelnosti studentov [Diagnostics of individual-style features of self-regulation in the educational activities of students]. Voprosyi psihologii, 4, 134-140.

Morosanova, V. I. (2004). Oprosnik "Stil samoregulyatsii povedeniya" [Questionnaire "Style of self-regulation of behavior"]. Moskva.

Morosanova, V. I. (2010). Samoregulyatsiya i individualnost cheloveka [Self-regulation and individuality. Moskva: Nauka.

Nasledov, A. D. (2004). Matematicheskie metodyi psihologicheskogo issledovaniya: analiz $i$ interpretatsiya dannyih [Mathematical methods of psychological research: data analysis and interpretation]. Sankt-Peterburg: Rech.

Teteruk, S. P. (2006) Formuvannia mekhanizmiv samorehuliatsii studentiv $v$ inshomovnomu prostori. (Dys. ... kand. psykhol. nauk). [Formation of mechanisms of self-regulation of students in the foreign language space. (Dis. ... Cand. Psychol. Sciences)]. Kyiv.

Chayka, V. (2006). Pidgotovka maybutnyogo vchitelya do samoregulyatsiyi pedagogichnoyi diyalnosti [Preparation of the future teacher for self-regulation of pedagogical activity]. Ternopil: TNPY.

Shavyro, H. (2014) Psykholohichni chynnyky samorehuliatsii povedinky studentskoi molodi v protsesi sotsializatsii. [Psychological factors of self-regulation of the behavior of student youth in the process of socialization]. Visnyk Kyivskoho natsionalnoho universytetu imeni Tarasa Shevchenka [Bulletin of Kyiv National Taras Shevchenko University], 1, 86-90.

Shevchenko, N. F. (2010) Rozvytok emotsiino-volovoi samorehuliatsii studentiv v umovakh vyshchoho navchalnoho zakladu. [Development of emotional-volitional self-regulation of students in a higher educational institution]. Pedahohichni nauky: teoriia, istoriia innovatsiini tekhnolohii [Pedagogical sciences: Theory, History Innovative Technologies], 1, 270-280. 
Schunk, Dale H.; Ertmer, Peggy A., Boekaerts, Monique (Ed); Pintrich, Paul R. (Ed); Zeidner, Moshe (Ed). (2000). Self-regulation and academic learning: Self-efficacy enhancing interventions. Handbook of self-regulation. - San Diego, CA, US: Academic Press. -783 p.

Schraw, G., Crippen, K.J. \& Hartley, K. Res (2006). Promoting Self-Regulation in Science Education: Metacognition as Part of a Broader Perspective on Learning. Research in Science Education. Volume 36 (1-2). - P. 111-139.

Sun, J.C-H. \& Rueda, R. (2012). Situational interest, computer selfefficacy and self-regulation: Their impact on student engagement in distance education. British Journal of Educational Technology. - Volume 43(2). - P. 191-204.

Zabгucky, K.M. (2008). Metacognition and learning. In N. Salkind (Ed.), Encyclopedia of Educational Psychology. - Thousand Oaks, CA: SAGE Publications, Inc. - P. 673-676.

Zimmermann B. (2008). Investigating Self-Regulation and Motivation: Historical Background, Methodological Developments, and Future Prospects. American Educational Research Journal. Volume 45 (1). - P. 166-183.

\title{
STYLISTIC FEATURES OF SELF-REGULATION OF BEHAVIOR OF FUTURE SPECIALISTS-PSYCHOLOGISTS
}

\author{
Oleh Rudiuk \\ Candidate of Psychological Science, \\ assistant professor of the department of \\ general psychology and psychological diagnostics \\ Rivne State University of Humanities \\ https://orcid.org/0000-0003-0200-1982.
}

DOI https://doi.org/10.35619/praprv.v1i16.221

\begin{abstract}
The article deals with the results of research of the stylistic features of selfregulation of behavior of future specialists-psychologists at different stages of their training. The results of the study reveal that the nature of development of basic regulatory processes (goals planning, significant conditions modeling, actions programming, evaluation and correction of results) and regulatory individual properties (flexibility and independence) of future psychologists has its own specific features at different stages of their educational and professional training.

In comparison with the first-year psychology students, psychology students of the fourth year show significantly higher degree of development of basic regulatory processes and regulatory individual properties. That is: general level of self-regulation as the ability to conscious selfregulation of arbitrary activity; flexibility as the ability to restructure and correct the system of selfregulation when external and internal conditions change; evaluation and correction of results as the ability to adequately and autonomously evaluate themselves and the results of their activities and behavior, as well as the stability of subjective criteria for evaluating the success of achieving results; modeling of significant conditions as a degree of development of ideas about the system of external and internally significant conditions for achieving the goals, their awareness, detail, adequacy; independence as a degree of development of regulatory autonomy; programming of actions as a degree of conscious construction of ways and sequences of own actions for achievement of the set purposes; planning the goals of activity as a degree of development of goalsetting mechanisms in terms of awareness and autonomy of the process of setting goals for activity, their effectiveness, realism, detail and stability.
\end{abstract}

Key words: self-regulation, regulatory processes, regulatory individual characteristics, components of self-regulation of behavior, psychology students, professional training. 